
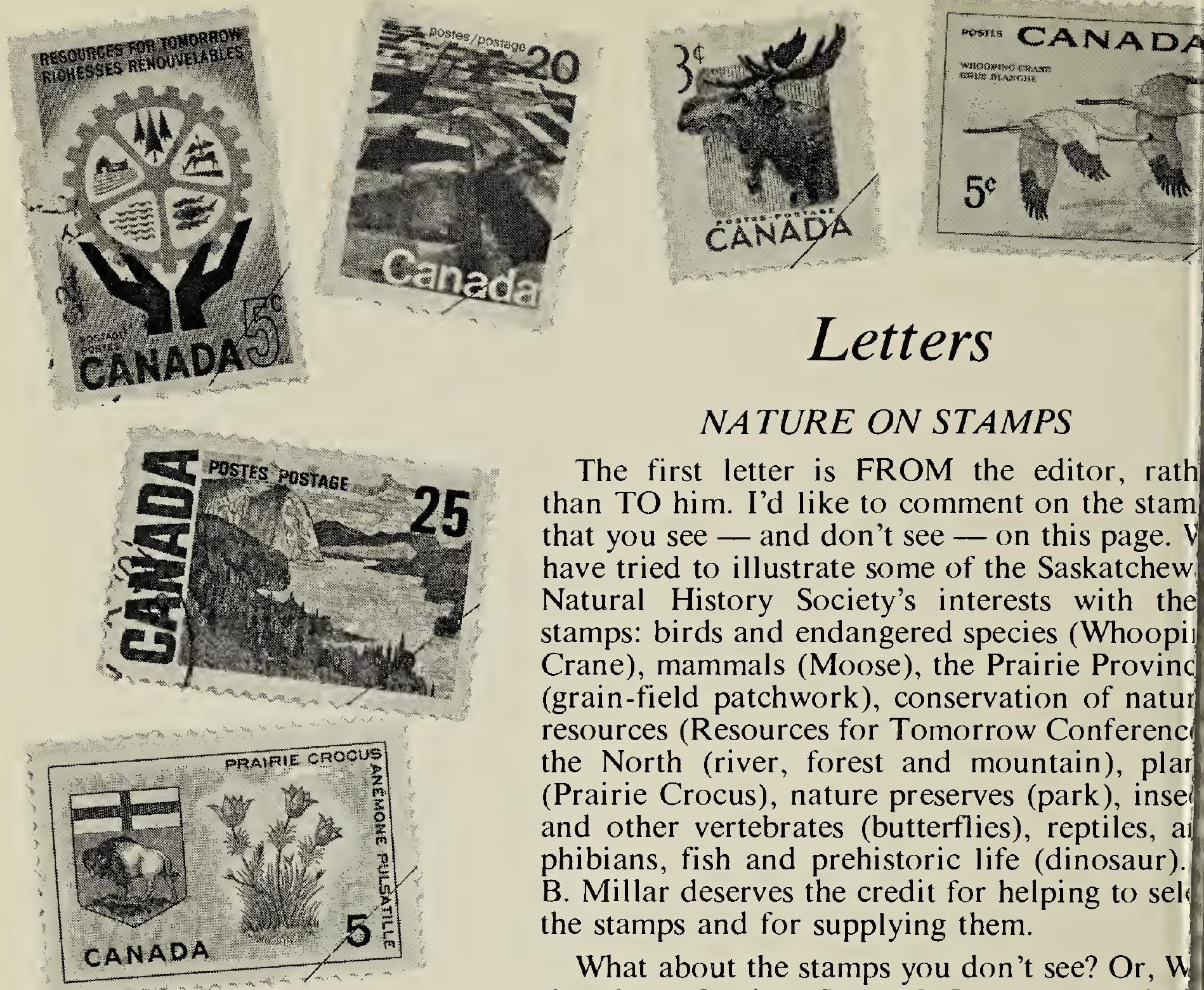

\title{
NATURE ON STAMPS
}

The first letter is FROM the editor, rath than TO him. I'd like to comment on the stam that you see - and don't see - on this page. V have tried to illustrate some of the Saskatchew. Natural History Society's interests with the stamps: birds and endangered species (Whoopil Crane), mammals (Moose), the Prairie Provinc (grain-field patchwork), conservation of natur resources (Resources for Tomorrow Conferenc the North (river, forest and mountain), plar (Prairie Crocus), nature preserves (park), inse and other vertebrates (butterflies), reptiles, al phibians, fish and prehistoric life (dinosaur). B. Millar deserves the credit for helping to sel the stamps and for supplying them.

What about the stamps you don't see? Or, W the three foreign Stamps? It was a real d appointment to find that Canada, with one of finest park and animal reserve systems in world, does not have a single stamp, let alon series, featuring this important aspect of culture. We found such stamps from the Uni States, Russia and elsewhere but finally settled one from Rwanda which, like other so-cal "under-developed" African nations, ha: development that our "developed" country d not have - grassland parks. And isn't it a sha that Canada, with some of the finest fo deposits in the world, has never devoted one more than 1,000 postage stamps to its prehiste animal life! Finally, it was a surprise not only find that there is such a place as Herm, a half: tion piece of the Channel Islands, But also tha least one of its 108 stamps depicts insects, cluding a Monarch Butterfly. A careful searcl Canada's postage stamps would suggest that are an insect-free nation.

People can learn much about a country fror stamps. However, Canada's stamps give the re: the world a distorted view of our sensitivit our environment. SNHS and similar societies probably bring about a remedy for this situat 1 If so, then, within a year or two, we might , have to go around the world for stamps to exp s; Canadian interests in Canada's environment Editor 


\section{CAN'T WHOOPING CRANES BE PROTECTED ON PRIVATE LAND?}

I am writing in regard to the group of ee Whooping Cranes that remained our district from September 26 to. tober 10, 1972.

For the first few days almost no one ard of them because they were away $\mathrm{m}$ a well travelled road, but soon y established their headquarters on a bble field next to a grid road. On tember 29 an Audubon member, a John Bode of 64 Lloyd Ave., nbrook, Long Island, New York, ived by lucky chance and he literally yed with the birds for 6 days, sleeping his car each night. He is an artist and otographer and was keenly interested th in getting photographs and seeing t no one bothered the birds. On Ocer 4 , he had to leave and I, along h other interested neighbors, tried to ep watch but in spite of our efforts pughtless and curious passers-by uld drive into the feeding ground and bhten the birds, some to try to get ser and others to make them fly.

Bob Turner of the Saskatchewan iseum of Natural History spent a iple of days observing the cranes, and ederal game officer from Edmonton ched them for one morning.

Dne incident which really worried us a report that two vehicles had ven in and five men with guns were $n$ walking towards the birds. At this I ned the police who said they'd ort it but couldn't keep watch all the e. Then I phoned the Conservation icer who drove out later the same day saw that the birds had retured. ple continued to disturb the birds so honed him again and tried to perde him to put up signs at the entrance he trail which led into the field. He 1 he didn't know what to put on such is, that he didn't believe he had the it to put them up and that only the d owner could object to people enng his field. He said maybe the five I with guns were just hunting other pe in the field. I told him that nitely wasn't so because in all the time Mr. Bode and myself had watched that field, absolutely no other game birds had landed there. He did sent out a young DNR helper to put up signs late the next day. (October 10). Unhappily, someone had been chasing the birds that morning and they had already left the area at about 10 a.m. I do hope they are now safely on their way to their winter home.

I do feel that if our beautiful cranes aren't given more protection than the authorities have given them here, there is no chance of their surviving. I know the territory is large and the game wardens have many duties but why couldn't local interested and dedicated people be given authority to protect the birds? I stopped one car load of people and they were most indignant, although they did as I asked.

I would be grateful if someone could answer these questions:

1. Who is is directly responsible for the safety of the cranes while they are here?

2 . Is the hunting supposed to carry on as usual, even into the field where cranes are feeding?

3. Can't signs be put up to keep people out of the fields whether or not the owner agrees? (In this case the owner had no objection).

4. What does the term "molesting the birds" mean? I asked the Conservation officer and he said the courts would have to decide that.

I do think more careful guarding is necessary along the migration route. It almost seems a crane has to be shot before any action is taken - and then it is too late. - Mrs. Edith Gardiner, Box 159, Kindersley, Sask.

\section{TO WALK IN THE WOODS}

The following story is one which I wrote for school. You may find it suitable to make people understand or appreciate our natural surroundings, if you wish, edit it, if not, fine. Here goes:

A walk in the woods can stir your heart in many different ways, depending on the season. 
To walk in the woods in spring is to hear the birds singing in the trees, and the flow of fresh, clear, cool water. To walk in the woods in spring is to see the snow leaving right before your eyes; to observe as the buds of trees and sprouts of grass have the slightest tint of green; to taste the air and feel a sense of a new beginning in your heart.

To walk in the woods in summer is to feel alive again; to see the insects, trees, grass, flowers, and all things that exist with you; to hear the rustle as a deer runs close by; to hear the Robin and its young. To walk in the woods in summer is to love what you sense with a warmth received from the sun.

To walk in the woods in fall is to see the earth preparing for a long winter's sleep. The birds are flocking, and the animals that stay are gathering food, for they sense the earth's hibernation, too. Just hear their busy chatter. Listen! Can't you hear the squirrels working their way across the leaf-covered ground? Can't you hear the leaves grumble and the wind rustle, as it throws many more to the ground?

To walk in the woods in winter is to see death, hear silence, and know that the earth is asleep. - Roberta Smith (Age 14), Endeavour, Sask.

\section{THE TWO LITTLE ORPHANS}

On one of our field trips, Mr. Lane, Chris Martin and I found a nestbox with two baby Mountain Bluebirds in it. The nest was in bad shape. It was all torn up and the babies were dying of hunger. We went on in the hope of finding a nest of Mountain Bluebirds with babies in it of the same size. We were trying to find foster parents for the two little orphans.

A little way down the road were three nests at the corner. The three of us split up to check the boxes. Chris found a nest with six Eastern Bluebirds, Mr. Lane's box had Tree Swallows and in mine I found six Mountain Bluebirds. This one was just right and we all went back and took the two little birds to the new nest. Unfortunately, it was too lat When we went back a week later $t$ little birds were not there. They mu have died and the parent birds had tak them away. - Steven McFarlane (a 9), $243-17$ th Steet, Brandon.

\section{PRESERVE ROAD ALLOWANCES}

\section{BY HUGO TIESSEN*}

The use of chemical sprays to destr the vegetation along road allowances quite common in many of the Ru Municipalities of Saskatchewan. I not aware of the scope of this spray program, but I will relate my experi, ces in connection with it.

Near Nisbet Provincial Forest, so of Shellbrook, a conservation-mind farmer and I toured several scenic $\mathbf{r}$ allowances, some of which w sprayed. The beauty of these trails quite startling; aspens, willows several varieties of shrubs gr alongside the faintly marked tra Those road allowances that w sprayed appeared hideous and sickly comparison, the leaves of the trees be brown and curled over.

The intention of the spray was destroy the trees and shrubs immedia alongside the trail so that farmers co transport their farm equipment over route to their farmland. In this case, idea of destroying the vegetation for purpose seemed completely pointles was told that adjacent roads provi the farmers adequate access to $t$ land. Besides, it would be impossibl 0 bring wide farm machinery along $t$ trails because the spray did not rem the trunks and branches of the trees shrubs.

The chemical spray had the effec damaging an otherwise scenic la scape. Along the road allowance could see a sharp transition betweer sickly vegetation and the hea vegetation.

While driving throughout Sas chewan one can see many road allo

*2604 Cascade St., Saskatoon. 


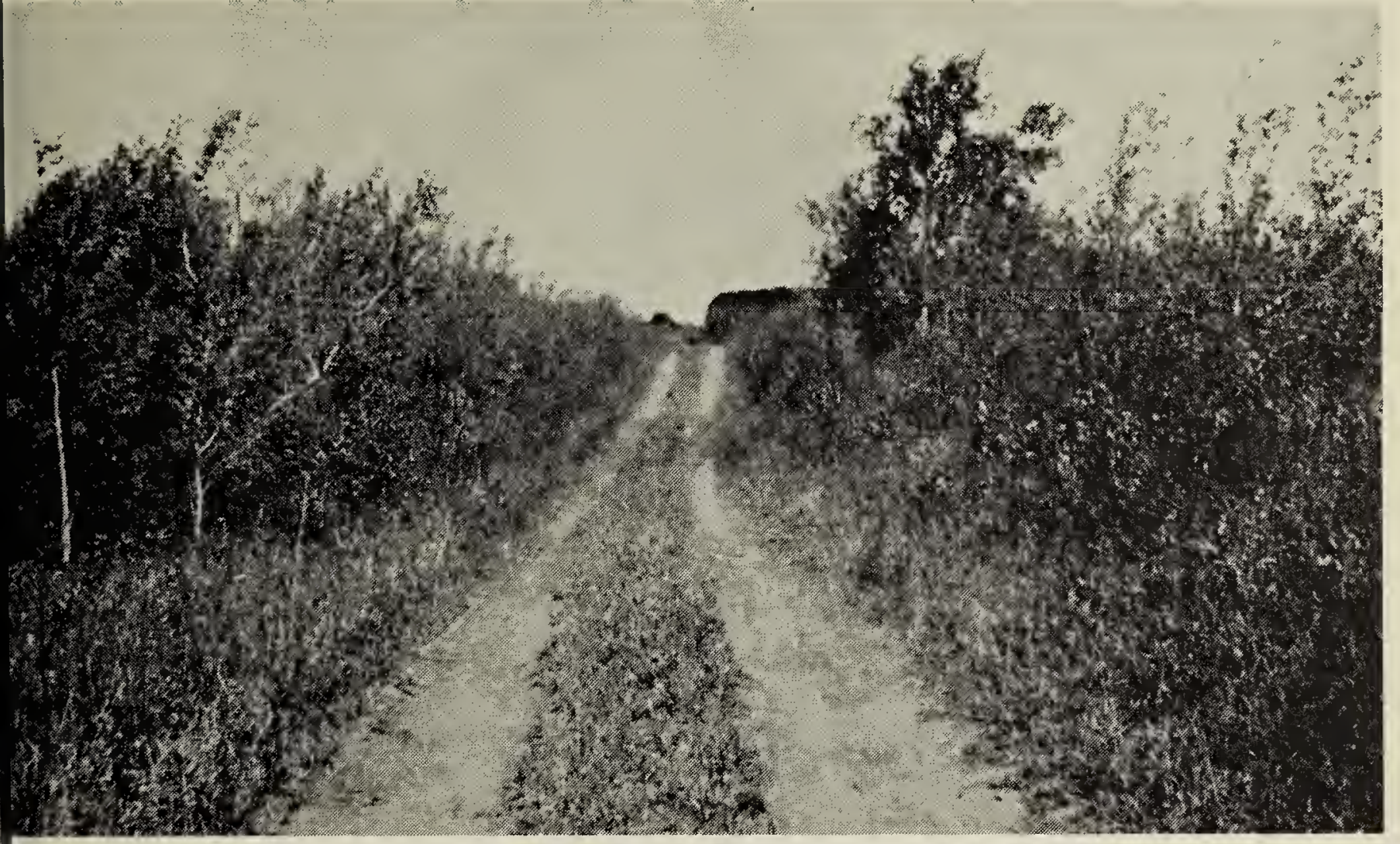

in a natural state except for two ruts the center. In many instances, the tetation on either side of the trail has en unaltered by man. Although road owances are only 99 feet wide, they en play an important role in viding a habitat for insects, birds d small mammals.

Rather than be destructive and waste reat amount of money destroying the intryside, municipalities should atpt to preserve these trails. Often the id allowance is the last remaining a of natural vegetation, as the hainder of the land has yielded to the $\mathrm{w}$ and is used for agricultural pures. I suggest that each municipality uld attempt to preserve at least 10 es of road allowance which have nic qualities - flowers, grass, bushes 1 trees. This would prevent the use of emical sprays and road-building fipment from destroying trails ignated for this purpose. This should possible because many of these trails located in remote areas of the nicipality and, consequently, there uld be little pressure to improve $\mathrm{m}$.

he need to preserve these trails is obus. Although the program would be ill in stature, it would be another hod of attempting to preserve scenic as in our landscape from wanton destruction. Such areas would provide an ideal place where people could go for a quiet walk in the countryside to enjoy the splendour of nature.

\section{GREATER PRAIRIE CHICKEN}

\section{AT LEADER, SASKATCHEWAN}

\section{BY DAVID R. M. HATCH*}

At noon on November 3, 1972, as I was eating dinner in a cafe in Leader, Saskatchewan, I overheard three American hunters discussing a grouse they could not identify and had shot earlier that day. I asked to see the bird and they showed it to me. It proved to be a Greater Prairie Chicken. The bird, an adult male, had a short, rounded tail, which consisted of 18 rectrices that were deep brown in colour and tipped by white. With the exception of the primaries, secondaries, tail and neckfeathers (pinnae), nearly all the other feathers were barred by white and brown in equal proportions. On each side of the neck was a set of elongated, rigid, pointed feathers. These pinnae were dark brown and each covered a patch of bare orange skin. Above the eye

\footnotetext{
* Manitoba Museum of Man and Nature.

190 Rupert Avenue,

Winnipeg, Manitoba R3B 0N2.
} 
was a much smaller patch of bare orange skin. This bird showed no hybrid characteristics.

Besides the Greater Prairie Chicken, these hunters had seven Sharp-tailed Grouse in their possession. The Prairie Chicken was midway in size between the largest and the smallest of these Sharptailed Grouse. The hunters had seen no other grouse of this type during the day and this particular Prairie Chicken was a lone bird flushed from a small bluff. The hunters claimed to have shot the Prairie Chicken 10 miles due east of Leader; however, when I showed them that location on a detailed topographical map they were a little vague in confirming it.

I tried unsuccessfuly to get the hunters to give the Prairie. Chicken to me so it could be presented to the Saskatchewan Museum of Natural History as a study skin. Upon discovering the significance of their kill they decided to keep the bird and have it mounted.

This is the first time in at least 20 years that a Prairie Chicken taken in Saskatchewan has been examined in the hand. This record lends further support to a recent well documented sighting of a Greater Prairie Chicken near Mortlach, Saskatchewan, reported by Frank Brazier in the September, 1972, Blue Jay.

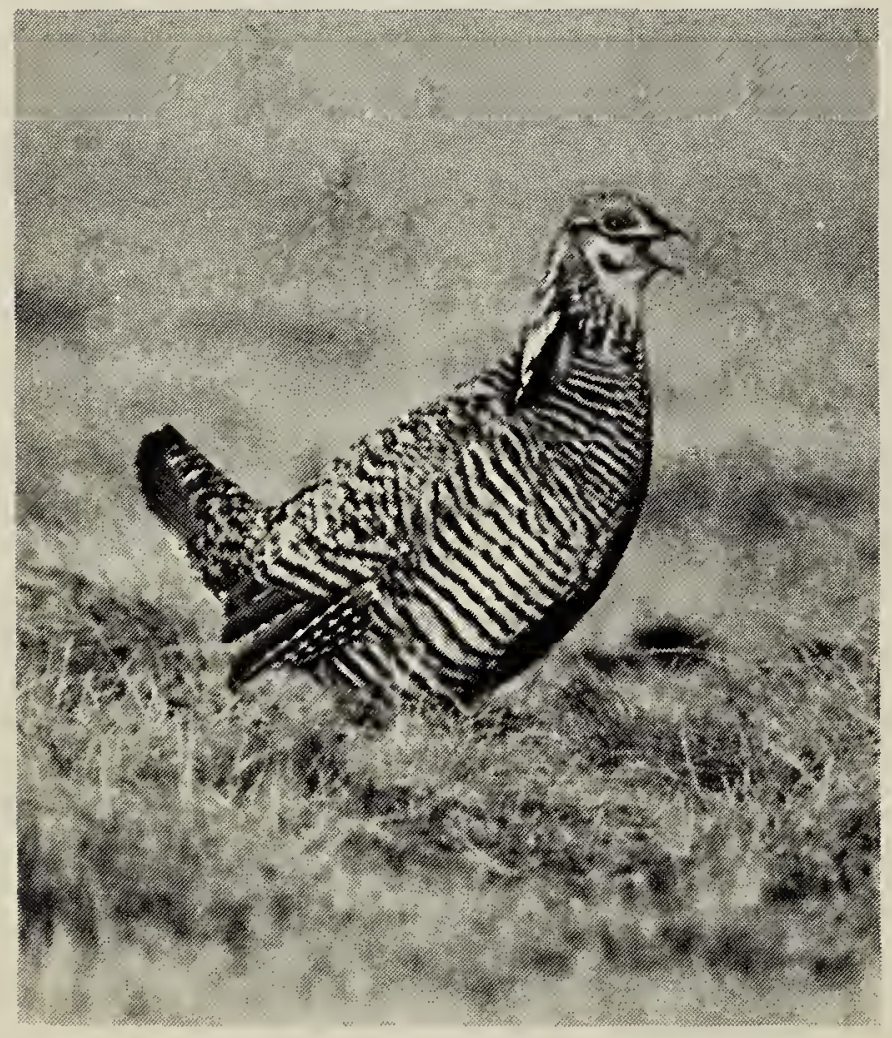

Prairie Chicken

Fred Lahrman

\section{OWL Notes}

\section{BY EVELYN CASSON*}

Last winter my sister and her husban did not return to the farm until Apri They were surprised to find that, in spi of the fact that the rabbits were so plet tiful around the countryside, their fru trees and bushes had not been harme This seemed strange as so many peop had lost fruit trees and raspberry can from the ravages of rabbits. It did $n$ take them long, however, to discover tl reason. High up in a large spruce tr about 10 feet from a bedroom windc they discovered a Great Horned $\mathrm{O}$ nesting.

The female was a large owl of a da gray colour touched with white here at there, with an under coat of bu showing through. Her "horns" we large, prominent tufts. The male was beautiful golden owl, large, but $n$ quite so large as the female.

Day after day we watched with gr interest as the owls incubated the eggs the sloppy, carelessly built nest, whi looked as if it would collapse in the fi strong wind. We did not climb up to how many eggs there were for obvic reasons; but finally one day our patie was rewarded! We discovered two flu white heads peeping out of the nest.

When the nestlings were only a days old, a big wind and rain sto came up. The next morning, when looked out, there appeared to be a bi white rabbit fur on the ground under tree. On further investigation we fou "the fur" to be one of the nestli which must have blown out of the during the storm and died.

This left only one little one. The few days later, much to our cons nation, we discovered the other li owl on the ground, but appare unharmed. Covered with a soft, w fluff he was about as big as a half-gr chicken. The large yellow eyes st: with deep distrust, and the sharp, str claws and beak (which he knew hor use if one was foolish enough to $c$ too near) were evident.

${ }^{*}$ Medstead, Saskatchewan 
For the first few weeks on the ground - seemed to think that the tree was his vn special one, for he snuggled up to it id did not move very far from it. Each orning about 5 o'clock the parents ould be on hand with breakfast. The other carried the food, nearly always a bbit, to the foot of the tree and would gin tearing it into pieces and literally amming it into her baby while the ther kept guard from the house or tree p.

What huge meals the baby ate and ow he grew! After the meal was hished the mother would clear the rubsh away and leave her baby on his vn. He would preen his feathers and ly up, baby that he was, and then uuld sleep and yawn, sleep and yawn e day away.

Toward evening he would start to get stless and start calling. The sound he ade was not a hoot but a sort of a bark at sounded for all the world like, Wha-a-t!" Finally about dusk his ther would arrive and serve another ge meal.

In a few weeks baby owl was almost e size of a full-grown chicken, and was vered with grey and white feathers. He ould fluff out his feathers to make mself look big and fierce when anyone me near and snap his beak and hiss at hy intruder. Nearby, the parents, hiden from sight, would send out warning lls - a sort of barking sound - two irks and then a snapping of their rong, cruel beaks.

About this time the baby owl began alking around. He would toddle off on s two unsteady, feathery legs, stuming along among the tall grass and ceds for all the world like a fat, little y. One day you would find him out in e field across the road, another time vay over under the trees in the poplar uff. Although you did not always see e mother, you knew by her calls that e was keeping careful watch. By this me the father must have gone for there d been no sign of him for many days.

Finally, when the baby owl was about month old and beginning to look quite own-up, we missed him. We hunted d hunted and were about to give up when we suddenly came upon him up in a tree about 10 feet from the ground. He had crept up a little dead tree that was slanted over and touching his nest tree and there he perched, by turns sleeping, yawning and preening his feathers. At this point he spent much time exercising his big, strong wings. He would stretch them out to their fullest length and then flap them vigorously, all the while stretching up onto his tiptoes.

A few days later we found him perched on an old wagon gear. He watched our approach, staring unblinkingly with his huge golden eyes until we were within about 5 feet of him. Suddenly he stretched up on tiptoes and, spreading his wings, swept away into the woods as silently as a shadow.

When two months old and apparently full grown he would often sit around the dugout on a post, preening his feathers or sleeping, but when night came he would begin his hoarse barking call. Since he did not seem to be fed any longer by his mother, he must have been catching his own food.

One night we began to hear the young owl continually calling "Wha-a-a-t, Wha-a-at" and then become quiet as if he were listening for an answer. Finally off in the woods, across the road, there came a deep "Whoo! Whoo!" and with what seemed to us a note of pure joy he called "Wha-a-t! Wha-a-t! Wha-a-t!" and sped away toward the sound like a silent grey streak.

\section{FIRST REPORT OF A GOLDEN-CROWNED SPARROW}

\section{AT CALGARY, ALBERTA}

\section{BY HAROLD W. PINEL* and CAROL J. ROBINSON**}

On October 12 and 13, 1972, we observed a Golden-crowned Sparrow at the Inglewood Bird Sanctuary at Calgary. It was first noticed at 1:50 p.m. on October 12 at a feeding station in the company of a single Whitethroated Sparrow. At 12:45 p.m. on Oc-

*1017-19th Ave., N.W., Calgary, Alberta.

${ }^{* *}$ Group Box 3, 9th Ave. and 22nd St., S.E., Calgary, Alberta. 
tober 13 , the sparrow was seen again at the feeder, this time in the company of about 40 House Sparrows, a Blackbilled Magpie and a female Ringnecked Pheasant. The Golden-crowned Sparrow was observed at intervals throughout the rest of the afternoon on October 13, either at the feeder or in adjacent shrubbery.

The standard field guides were used to identify the sparrow. ${ }^{2}:$ The distinctive pattern and colours of the crown were noted: briefly, the crown was brown with the forecrown being a dull yellow color, making the bird an immature or a winter adult. The second winter plumage as depicted in one book is a close representation of the bird seen by us." Other features noted were two white wing bars, a dusky bill and a faintly barred chest.

This appears to be the first record for the Calgary area and the second known record away from the mountains in Alberta. ${ }^{4}$ The other non-montane report is by M. Cole of Red Deer who observed three Golden-crowned Sparrows at her feeding station in October, 1939.' Associated with the Golden-crowned Sparrows were Slate-colored Juncos, a small flock of Oregon Juncos, a few Song Sparrows, and about 12 Whitecrowned Sparrows and House Sparrows.

'Cole, M. P. 1941. Bird visitors at Red Deer, Alberta. Can. Field-Nat. 55:5.

'Peterson, R. T. 1969. A field guide to western birds. Houghton Mifflin Company, Boston.

'Robbins, C. S., B. Bruun, H. Zim and A. Singer. 1966. Birds of North America. Golden Press, New York.

${ }^{4}$ Salt, W. R., and A. L. Wilk. 1966. The birds of Alberta. Gov't of Alberta, Dept. of Ind. and Devel. Queen's Printer, Edmonton.

\section{Ever seen a bluejay questionnaire?}

Check the first and last pages of this issue.

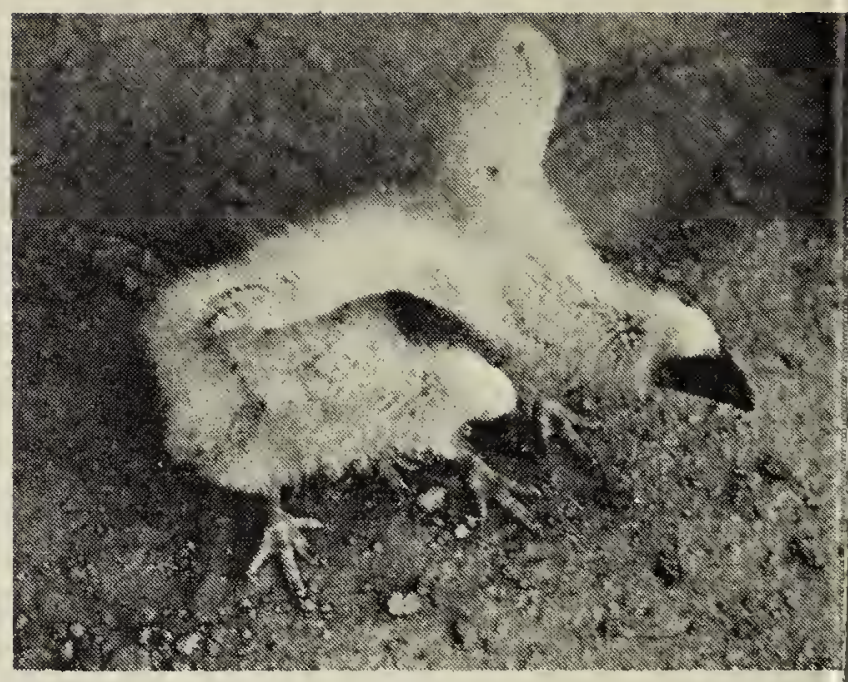

Young Turkey Vultures July 16,1972

\section{CAVE-NESTING TURKEY VULTURES OF THE SOUTH SASKATCHEWAN}

\section{BY JOE W. SCHMIDT*}

One weekend at the end of $\mathrm{Mc}$ 1972, I was driving my dune-bug along the South Saskatchewan riv valley in the Lancer area. Since an ad Turkey Vulture had been spotted Gordie Johnson the week before, two of us, with Ian Harnett and C: Fuller, looked for a suitable nesting si We found a large cave in the river cli and, as we approached, the female ca flying out. Two eggs were being cubated about 4 feet in from the ci mouth. This was not only the first ne but the first vulture I had ever seen. T was quite an experience for me.

Dr. Stuart Houston had told me one of our trips a few years ago, $t$ vultures had been sighted along the ri valley, but he had never seen a nest $p$ sonally. We returned with Dr. Hous on June 18 to find the eggs had not hatched. On our final visit on July he banded the two young, adding a $r$ species to his banding list.

NOTE: Frank Martens of Spiritwood Conservation Officer Les Arndt found an cupied Turkey Vulture nest on an islan Chitek Lake in 1970. It was a burrow al ॥ 10 inches in diameter on a 60-degree-s e bank near the shore. Adult vultures had in seen around the island for two sumi : previously - S. D. Riome.

(Previous Saskatchewan nesting record 1969 were summarized in the Blue Jay 2'7 - Ed.)

*3456 Caen St., Saskatoon 


\section{SIGHT RECORD OF THE}

\section{ERRUGINOUS HAWK}

\section{BRITISH COLUMBIA}

\section{BY PETER L. McLAREN and \\ MARGARET A. McLAREN*}

The Ferruginous Hawk is an uncomon raptor of the plains of North merica. The breeding range of the ecies extends south from eastern ashington, southern Alberta, southern askatchewan and southwestern Ianitoba. ${ }^{1}$ Its status in British Columa is hypothetical, based on several aht records at Osoyoos in 1922 and tother at Sumas in $1866 .{ }^{2}$

At 9:30 a.m. on August 12, 1972, hile driving along the trans-Canada ighway in Yoho National Park, we obrved an adult male Ferruginous Hawk aring overhead at the western tip of apta Lake, about 9 miles from the stern boundary of the park. We wated the bird for about 15 minutes with e aid of $7 \times 35$ binoculars, at distances as little as 30 feet. The sky was oudless and the sun was directly at our cks. During the course of its circlings were provided with excellent views both the ventral and dorsal portions the body and we noted all the key entification points for this species: the hitish tail, the dark $\mathrm{V}$ formed by the athers of the legs, the rufous elbows d the dorsal wing windows.

The sighting of this bird represents e first record of the species for Yoho ational Park (D. H. MacMillan, Park pt., pers. comm.). Its presence in the inadian Rockies is not unknown, the ecies having the status of a rare visitor both Banff and Jasper National rks. It is possible that these appearces in the mountains are the results of st-breeding wanderings by members the breeding population in southern berta.

fwn, L., and A. Amadon. 1968. Eagles, Hawks nd Falcons of the World. 2 vol. (945 pp.). IcGraw-Hill, New York.

unro, J. A., and I. McT. Cowan. 1947. A Review $f$ the Bird Fauna of British Columbia. 285 pp. ritish Columbia Provincial Museum Special ublication No. 2.

oyal Ontario Museum and Department of logy, University of Toronto, Toronto, Ontario

\section{A RECENT}

\section{BLACK-FOOTED FERRET}

\section{RECORD FOR SOUTHERN ALBERTA}

On the morning of August 9, 1972, my wife, my brother-in-law and I left Elkwater in the Cypress Hills to go birdwatching in the Manyberries-Pakowki Lake area of southeastern Alberta. At 1:20 p.m., we reached the west end of Pakowki Lake some 7 miles south of the nearest town, Etzikom. At 1:30 p.m., my brother-in-law discovered the carcass of a mammal about 4 feet above the ground on the top of a concrete piling supporting the bridge which crosses over the lake. After close scrutiny of the carcass, I identified it as that of the rare Black-footed Ferret. To confirm the identification, I walked back to the car to get The Mammals of Alberta. ${ }^{2}$ The identification was verified.

The long slim body, the stubby muzzle, the black-tipped tail, the black feet and legs, and the diagnostic black face mask were all noted. The dental formula was even checked and turned out to be $\frac{3-1-3-1}{3-1-3-2}=34$ which is characteristic of some members of the weasel family, the Black-footed Ferret being one. The death was not recent because pelage was lacking in the throat, neck, chest, and flank regions, and because part of a pigeon nest containing two eggs was situated on the lower back and upper legs region of the body. I couldn't determine the cause of death.

There are few records of the Blackfooted Ferret in Alberta. J. D. Soper states "Seton ... refers to a specimen from Calgary recorded in D. G. Elliot's Catalogue of Mammals of the Field Museum, 1907, p. 448. Anderson (1946) mentions a specimen collected in 1907 on the Blackfoot Reserve, near Gleichen, and another at Rosebud. Since that time extensive field work by field-naturalists in southern Alberta has apparently failed to detect further occurrences." Since 1964, however, there has been another sighting of the Black-

*1017-19 Ave. N. W.,

Calgary, Alberta. 
footed Ferret in Alberta besides that made by me. At 4:30 p.m. on September 13, 1967, Dr. M. Skirrow clearly observed a Black-footed Ferret running across the road one mile north of Connemara which is approximately 40 miles south of Calgary (Calgary Field Naturalists' Society records). In adjacent south-western Saskatchewan, the Black-footed Ferret has been recorded in the past from 15 different localities. ${ }^{1}$

Based on the fact that the main food supply of the Black-footed Ferret is the prairie dog, a species which has not been definitely recorded for Alberta, and the fact that so few records exist for the ferret in southern Alberta, I agree with Soper (1964) in concluding that the few occurrences should be regarded as purely extralimital.

Ed Note: We hope that the specimen was collected and deposited in a museum. This should be done with any rare or endangered species found dead. Even the skeleton or a part of it is worth preserving. If the animal is too big or it is otherwise impractical to pick it up immediately, the nearest wildlife official should be notified.

'Beck, W. H. 1958, A Guide to Saskatchewan Mammals, Spec. Publ. No. 1, Sask. Nat. Hist. Soc., Regina.

'Soper, J. D. 1964. The Mammals of Alberta. Gov't of Alberta, Dept. Ind. and Devel., Queen's Printer, Edmonton.

\section{DOMESTIC CAT CATCHES A VARIETY OF WILDLIFE}

\section{BY DENNIS C. JOYES*}

(NOTE: This article from outside our usual area is included in hopes of encouraging people from the Prairies and North to let us know about their observations on the food of domestic cats. Ed.)

A domestic cat recently arrived at our ranch and gave birth to a litter of kittens. The cat was apparently accustomed to living in the wild for she was extremely wary and preferred to hunt in the surrounding fields and pastures.
When I first saw her she was feedir on a road-killed Whitetail Jackrabbi Later she was seen bringing in your jackrabbits, deer mice and shrews b her favorite hunting ground was colony of Richardson's Groun Squirrels. I once counted nine fresh killed ground squirrels in the old bat where she had her kittens.

Not content with only gophers si once caught a full grown Pintai possibly while the duck was on its ne: Small birds were also hunted especial House Sparrows, Western Kingbir and Brewer's Blackbirds which a abundant around ranch shelterbelts at corrals. The nests of House Sparro were often accessible and once locat were usually raided until empty.

The cat was once seen eating Smooth Green Snake but she avoid frogs and salamanders. The only inser I observed being eaten were bla crickets.

It did not occur to me at the time attempt to enumerate the prey brous in by "Mama," as the cat came to called, but she did provide a rand sample of the species hunted domestic cats on the prairies. Simi food habits have been recorded for $c$ in Oklahoma, California and Te although with local rather than north Plains species represented. ${ }^{2}{ }^{4}$ Instan of cats preying on ducks, however, not well known and have been cc firmed, so far as I know, only by $E$. Hubbs. ${ }^{2}$ Ducks eaten in T. Eberhar sample were thought to have br carrion or garbage.'

'Eberhard, Thomas. 1954. Food Habits of P sylvania House Cats. J. Wildl. Manage. 18: 286.

${ }^{2}$ Hubbs, E. L. 1951. Food Habits of Feral H Cats in the Sacramento Valley. California and Game 37: 177-189.

${ }^{3}$ McMurray, F. B. and C. C. Sperry. 1941. For Feral House Cats in Oklahoma, A Pro ss Report. J. of Mammalogy 22: 185-190.

${ }^{4}$ Parmalee, P. W. 1953. Food Habits of the House Cat in East-Central Texas. J. V Manage. 17: 375-376.

*Westby, Montana 
ARIATIONS IN

\section{IREWEED and BLUEBERRY}

\section{Y MRS. H. D. BOBIER*}

For many years there has been a patch white Fireweed growing by a roadde in Rapid View, Saskatchewan. The irple variety grows beside it but there bes not seem to be any crossbllination as the white flowers never ive a trace of pink or mauve. The aves and stems are also a brighter een. This variety apparently does not ed readily as there are never more than few specimens each year.

Last August while berry-picking near e Beaver River, I came across a small tch of "black" Canada or Velvetleaf ueberries the most common species und in Saskatchewan. As far as I uld see, there was no difference except e color. This was partly due to a lack "bloom." The black berries were not tart as the blue ones. Next spring I am ing back to see if the flowers are difrent.

apid View, Sask

\section{Hearg And}

\section{THE SNOWS OF YESTERYEAR}

Thirty years ago the first Christmas d censuses were reported in the Blue $y$, from Nipawin, Saltcoats, Scott. eho, Skull Creek, Tullis and Yorkton, d Maurice G. Street's comment was oted as expressing the general enIsiasm for the new project: "This is - first time I have ever taken a Christis bird census, and I was quite sursed at the number of species and iniduals seen when all totalled up." purice's own count at Nipawin on cember 26,1942 , covering an area of uce muskegs and jackpine ridges png the Saskatchewan River, duced 18 of the total of 30 species orded for the province: Goshawk, 1 ; ruce Grouse, 1; Ruffed Grouse, 2: llow Ptarmigan, 9; Great Horned
Owl, 3; Hairy Woodpecker, 2; Downy Woodpecker, 3; Canada Jay (as it was known then), 7; Blue Jay, 11; Magpie, 4; Black-capped Chickadee, 23; Hudsonian Chickadee, 9; Golden-crowned Kinglet, 5 (with the Editor's terse comment "no details" suggesting that this was then regarded as an unusual winter record); Bohemian Waxwing, 28; English Sparrow, 43; Evening Grosbeak, 14; Pine Grosbeak, 8; Redpoll, 271.

The Blue Jay in which these first counts appeared (January-March, 1943) was the second number of the first issue. The first number of this mimeographed newsletter had appeared at the end of 1942 as the "official bulletin of the Yorkton Natural History Society," having as its object "to foster an active interest in all branches of nature study, and to promote the conservation of all wild life; also to act as a connecting link between nature lovers in Saskatchewan."

In the first number the Editor, Mrs. I. M. Priestly, had explained about the Christmas Bird Census sponsored by the Audubon Society. "In Saskatchewan," she conceded, "the climate at that season of the year makes it rather difficult to comply with all regulations, one of which requires observers to be in the field for at least six hours. However, a provincial bird count of our own would be most interesting." Counters were then promised that their results would be published in the next Blue Jay, and the annual Saskatchewan Christmas Bird Count was born.

Beefs or bouquets about the "Blue Jay"?

Use the form at the front or back of this issue to let us know. 